\title{
Malignant Lung PEComa
}

National Cancer Institute

\section{Source}

National Cancer Institute. Malignant Lung PEComa. NCI Thesaurus. Code C142785.

A malignant lung tumor that arises from perivascular epithelioid cells (PECS). 